\title{
Quality characteristics of smoked duck using natural curing agent
}

\author{
Yeon Ok Park* \\ Dept. of Food and Nutrition, Songwon university, Gwangju 61756, Korea
}

천연 염지제을 이용한 훈제오리의 품질특성

\author{
박연옥* \\ 송원대학교 식품영양학과
}

\begin{abstract}
The objective of this study was to examine quality characteristics of a smoked duck marinated in natural curing agents containing extracts of pear by sugar, celery powder, and vitamin $\mathrm{C}$. We evaluated the composition food additives residue and total plate count, chromaticity, sensory properties, total polyphenol contents, 2,2-Diphenyl1-picrylhydrazyl (DPPH) radical scavenging effect of general smoked duck (GSD) and natural smoked duck (NSD). The nitrite ion, antioxidant and sodium glutamate of NSD were not detected. The lightness, yellowness and redness of the two smoked duck decreased significantly as growing longer storage days. The total plate count (CFU/g) of coliform bacteria of two smoked duck were not grown. The sensory properties showed that NSD was higher than GSD in the aspect of taste, texture and overall preferences. The total polyphenol contents and DPPH radical scavenging effect of NSD were higher than those of GSD. These results suggested that it was possible to manufacture a smoked duck marinated in natural curing agents including extracts of pear by sugar, celery powder, and vitamin $\mathrm{C}$ for the improvement of safety and quality.
\end{abstract}

Key words : extract of pear by sugar, celery powder, vitamin C, natural curing agent, smoked duck

\section{서 론}

오리고기는 양질의 단백질과 필수지방산을 고루 함유하 여 다른 육제품에 비해 혈중 콜레스테롤 함량이 낮아 생활 습관병을 예방할 수 있는 우수한 건강식품으로 알려져 있다 (1). 특히 훈제오리는 가정에서 취급이 용이하여 손쉽게 조리할 수 있으며, 국내 대형 오리고기 가공 업체에서 홈쇼 핑을 통해 훈제오리고기의 판매를 증가시켜 그 소비가 증가 하였다(2,3). 그러나 2015년 세계보건기구(world health organization, $\mathrm{WHO}$ ) 산하 국제암연구소(international agency for research cancer, IARC)에서 "소시지나 햄 등 육가공식품

*Corresponding author. E-mail : smilegem0512@songwon.ac.kr Phone : 82-62-360-5868, Fax : 82-62-360-3971

Received 27 April 2016; Revised 29 June 2016; Accepted 6 July 2016

Copyright (c) The Korean Society of Food Preservation. All rights reserved.
이나 붉은 고기를 섭취하는 것이 직장암이나 대장암을 유발 할 가능성이 있다." 고 보고서를 발표(4) 함으로 인해 국민 들의 훈제식품에 대한 불안감이 증가되어 훈제오리의 소비 가 감소하였다. 실제로 식품의약품안전처가 2010 2013년 국민건강영양조사를 분석한 결과(5), 우리 국민의 가공육 섭취량은 1 일 평균 $6.0 \mathrm{~g}$ 수준으로 $\mathrm{WHO}$ 가 발표한 가공육 매 $50 \mathrm{~g}$ 섭취 시 암 발생률이 $18 \%$ 씩 증가하는 내용을 참고할 경우 우리 국민의 가공육 섭취 수준은 우려할 정도 는 아닌 것으로 보고 하였다. 그러나 국민의 불안감은 감소 되지 않고 있으며 지속적인 가공육과 적색육에 대한 연구 대책이 필요한 실정이다. 따라서, 최근에는 훈제오리 제조 현장에서 국민들에게 보다 안전한 먹거리 창출을 위해 염지 중 들어가는 합성 산화방지제나 발색제, 글루타민산나트륨 등을 다시마(6), 울금(7), 산야초 발효액(8), 오디(9) 등 천연 기능성 소재로 사용하는 3 무 훈제오리 제품들을 선보이고 있다. 그러나 국내에서 훈제오리고기와 관련한 연구는 염 지제가 훈연오리의 육색 특성에 미치는 영향(3)이나 훈연 
오리고기의 판구이 수율 및 풍미평가(10), 훈연 오리고기의 저장 특성(11) 등 일부의 연구만 수행되어 훈제오리에 관한 체계적인 연구가 더 필요하다.

JECFA(Joint FAO and WHO Ex-pert Committeeon Food Additives)는 식품첨가물을 식품의 외관, 향미, 조직 또는 저장성을 향상시키기 위한 목적으로 식품에 보통 미량으로 첨가되는 비영양성 물질이라고 정의하였다(12). 염지는 원 료육에 식염, 질산염, 아질산염, 향신료, 설탕 및 조미료를 넣어서 처리하는 방법으로 저장성을 높이고, 풍미, 색, 보수 성을 좋게 하는 역할을 한다(13). 그러나 식품첨가물 중 훈연식품의 염지제로 사용되는 아질산나트륨이나 산화방 지제, 글루타민산나트륨(MSG) 등은 안전한 것 이라고 하더 라도 순도나 사용법 등에 따라 인체에 해로운 영향을 끼치 는 경우가 보고되고 있어 많은 연구자들이 식품첨가물과 두드러기나 혈관부종, 접촉성피부염, 아토피피부염과 천식 등 다양한 과민반응에 대한 기전을 연구하고 있다(14). 특히 아질산나트륨은 육색의 발색과 안정화, Clostridium botulinum 의 성장과 독소 생성 억제, 풍미 향상, 산패취 발생 억제 등의 중요한 역할을 하지만, 다량 섭취하면 methemoglobin 을 일으키거나 발암성 nitrosamine을 생성하는 것으로 알려 져 있다(15). 따라서 식품첨가물을 대신할 안전하고 위생적 인 천연물질을 찾는 노력이 필요하다. 천연물신약연구개발 촉진법 정의에 의하면 천연물은 사람의 힘을 가하지 아니 한 천연 그대로의 물건 혹은 육상 및 해양에 생존하는 동. 식물 등의 생물과 생물의 세포 또는 조직배양산물 등 생물 을 기원으로 하는 산물'을 의미한다(16). 그래서 천연 염지 제는 염지 기능을 가지는 천연물 성분이 함유된 제품이라고 정의해 볼 수 있다.

본 연구의 재료로 사용된 배는 염지제의 설탕을 대신하 여 사용되는데 한의학에서 '이' 혹은 ‘이자'라고 하며 독특 한 단맛과 시원한 맛을 지닌 알칼리성 식품으로 성질은 차갑다(17). 배 과실 열량의 주성분은 탄수화물이며, 이중 단맛을 내는 당분은 10 13\%로 품종에 따라 차이가 많다. 그리고 식이섬유 함량이 높아 변비 및 정장작용이 탁월하다 (18). 또한 최근 많은 연구에서 배에 chlorogenic acid, rutin, procyanidins, catechin, epicatechin, arbutin(4-hydroxyphenyl$\beta$-D-glucopyranoside)등 폴리페놀(polyphenol), 플라보노이 드(flavonoids)등의 성분이 많이 함유되어 있어 항암, 항염, 및 항산화 효과가 뛰어난 것으로 밝혀지면서 많은 관심을 끌고 있다(19-22). 특히, 배는 흡연이나 훈제, 불고기 등을 섭취 후 먹으면 체내 발암성 다환족방향성탄화수소 (polycyclic aromatic hydrocarbons, PAHs)의 대사산물인 1-hydroxypyrene(1-OHP)의 뇨 중 농도가 유의하게 감소하 여 산화적 손상지표인 malondialdehyde(MDA)를 억제하는 효과가 보고되었다(23). 셀러리는 질산 함유량이 높고 셀러 리 자체의 풍미가 육제품과 잘 어울리기 때문에 셀러리를 천연발색제로 사용하고 있다(24). 또한 셀러리는 피를 맑게
하고 혈압을 내리게 하는 효과가 있으며 날 것으로 씹어 먹으면 변비에도 좋고 류머티즘에 효과가 있다고 알려졌다 (25). 그래서 셀러리는 천연발색제로서 3 무 훈제요리의 염 지제로 이용되고 있다. 비타민 C는 천연 항산화제로 유리라 디칼에 전자를 줌으로써 비타민 $\mathrm{E}$ 와 함께 유리라디칼 제거 제로 작용하고 면역 수행 중 유리라디칼로부터 생기는 산화 적 손상을 막아 면역작용을 향상시키는 작용을 하고 그 외에도 항균작용, 자연살세포 활성 등 면역반응에 영향을 미친다고 보고되었다(26).

본 연구는 훈제오리 제조 시 염지성분으로 사용되는 아 질산염, 산화방지제, 글루타민산 나트륨을 빼고 배당침액 을 설탕 대신 사용하고 샐러리파우더를 천연발색제로, 비 타민 C를 천연산화방지제로 사용하여 천연염지제가 일반 식품첨가물을 대체할 수 있는지 가능성을 알아보고자 실시 하였다. 또한 천연훈제오리의 이화학적특성을 분석하여 소 비자가 믿고 소비할 수 있는 기능성 고부가가치 제품 개발 의 기초자료로 삼고자 하였다.

\section{재료 및 방법}

\section{실험 재료}

우리나라에서 재배되는 배 품종은 중생종이 $89.3 \%$ 차지 하며, 그 중 신고가 전체 재배면적의 $81.5 \%$ 를 차지하는 주품종(27)으로 본 연구에서는 신고를 이용하여 배당침액 을 제조하였다. 배는 나주에서 '신고' 품종으로 2011년 10 월 구입하여 Fig. 1과 같은 과정으로 배당침액을 제조하였 다. 배를 잘 씻은 후 물기를 제거하고 과심만 도려내어 껍질 째 $1 \mathrm{~cm}$ 두께로 잘라 배와 황설탕을 $1: 1$ 의 비율로 섞어 항아리에 켜켜이 담아 맨 윗부분을 설탕으로 덮어 배와 공기가 맞닿는 부분을 줄인 후 밀봉하여 $25^{\circ} \mathrm{C}$ 실온에 3 개월 저장하였다. 약 2 주 동안은 주 2 회 정도 항아리의 위,



Fig. 1. The manufacture process for pear extract using sugar 
아래를 저어 설탕이 잘 녹을 수 있도록 하였으며 약 100 일간을 발효시킨 후 배를 건져내고 시료로 사용하였다. 셀 러리 파우더와 비타민 C는 염지제 전문업체(e-Food Co., Chungju, Korea)에서 구입하여 사용하였다.

오리는 나주에 위치한 도축장에서 매입하였으며 일반 염지제와 천연 염지제는 전문 판매 업체(e-Food Co., Chungju, Korea)를 통하여 구입하였다. 본 연구에서 사용한 염지제와 염지 농도는 Table 1과 같이 오리고기 $100 \mathrm{~kg}$ 당 함량으로 계산하여 사용하였다. 염지는 원료육에 식염, 질 산염, 아질산염, 향신료, 설탕 및 조미료를 넣어서 처리하는 방법으로 일반 염지제는 발색제, 에르솔빈산, 글루탐산나 트륨 등 식품첨가물이 들어있는 염지제를 사용하였다. 그 리고 천연염지제는 발색제, 산화방지제, 글루타민산나트륨 을 빼고 배당침액과 셀러리파우더, 비타민 $\mathrm{C}$ 를 첨가하였다. 훈연과정은 실제 나주에 위치한 훈제오리 전문 업체의 제조 과정을 기본으로 실시하였다. 훈제오리 제조과정은 오리뼈 를 발골 한 후 약 24 시간 동안 텀블러에서 여러 가지 재료를 넣어 만든 염지제와 함께 진공 텀블러(Micro 2000, Suhner, Switzerland)에서 혼합 $\left(12\right.$ 시간 $\left./ 2 \pm 2^{\circ} \mathrm{C}\right)$ 을 실시하였다. 이후 훈연 오리고기는 훈연기(IT-90404, Intertek, Korea)에서 훈 연 $\left(15\right.$ 분 $/ 50^{\circ} \mathrm{C}$, 습도 $\left.40 \%\right)$ 하고 다시 훈연 $\left(30\right.$ 분 $/ 60^{\circ} \mathrm{C}$, 습도 $0 \%$ ) 후 가열 (심부온도 $75^{\circ} \mathrm{C}$, 습도 $99 \%$ )를 거쳐 제조되어 $15^{\circ} \mathrm{C}$ 이하 냉장고에서 냉장 보관되었다(Fig. 2).

Table 1. Comparison of the curing ingredient of the GSD and NSD smoked duck

\begin{tabular}{lcc} 
& (unit: kg/duck meat $100 \mathrm{~kg}$ ) \\
\hline \multicolumn{1}{c}{ curing ingredient } & $\mathrm{GSD}^{1}$ & $\mathrm{NSD}^{2}$ \\
\hline color fixing agent(add nitrite ion) & 0.98 \\
Natural color fixing agent(not add nitrite ion) & - & 0.31 \\
Casein & 0.60 & 0.60 \\
Whey & 0.30 & 0.30 \\
Salt & 0.39 & 0.39 \\
Sugar & 0.38 & - \\
Garlic & 0.04 & 0.04 \\
Onion & 0.03 & 0.03 \\
MSG & 0.05 & - \\
Red powder & 0.04 & - \\
Erythorbic acid & 0.07 & - \\
Beef powder & 0.10 & 0.10 \\
Vitamin C & - & 0.04 \\
Celery powder & - & 0.07 \\
extracts of pear by sugar & - & 0.38 \\
\hline
\end{tabular}

${ }^{1)} \mathrm{GSD}$, general smoked duck.

${ }^{2}$ NSD, natural smoked duck.

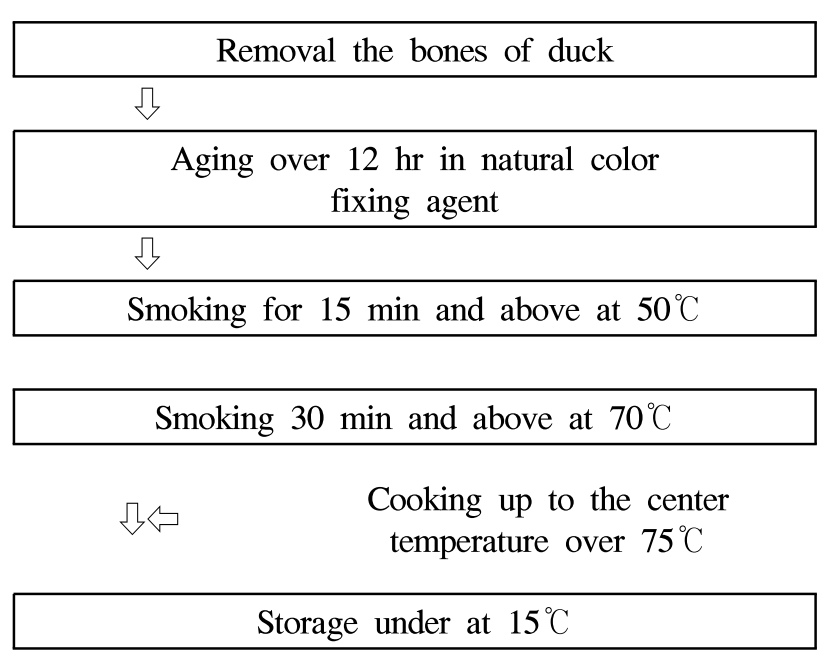

Fig. 2. The manufacture process of smoked duck.

식품 첨가물 함량

아질산염 잔존량은 $\mathrm{AOAC}$ 의 colorimetric 방법(28)에 따 라 분석하였다. 시료 $5 \mathrm{~g}$ 에 증류수 $50 \mathrm{~mL}$ 를 가하고, $40^{\circ} \mathrm{C}$ 의 수조에서 10 분간 가열한 후 포화 $\mathrm{HgCl} 5 \mathrm{~mL}$ 를 넣고 $80^{\circ} \mathrm{C}$ 에 서 2시간 동안 다시 가열한 후 냉각하여 여과하였다. 여액 $10 \mathrm{~mL}$ 에 sulfamilamide $1 \mathrm{~mL}$ 를 첨가하여 실온에서 15 분간 방치한 다음 $540 \mathrm{~nm}$ 로 흡광도를 측정하였다.

산화방지제 함량 분석은 Tanimura 등의 방법(29)을 참고 하여 시험용액을 조제하여 사용하였다. 표준용액과 시험용 액은 고속액체크로마토그래프에 주입하여 동일하게 실험 하였으며, 컬럼은 역상계 컬럼인 Nova-PaK $\mathrm{C}_{18}$ (Water Co., $3.9 \mathrm{mmX} 150 \mathrm{~mm}, 4 \mu \mathrm{m}$, Milford, Massachusetts, USA)으로, 이동상의 유속은 분당 $1 \mathrm{~mL}$ 로서 이동상 $\mathrm{A}$ 는 아세토니트 릴·메탄올, 이동상 $\mathrm{B}$ 는 $5 \%$ 초산을 사용하여 기울기용리 $\left(\mathrm{A}: \mathrm{B}=40: 60 \rightarrow 90: 10\right.$ (15분)로 UV $280 \mathrm{~nm}$ (Waters $\left.{ }^{\mathrm{TM}} 486\right)$ 에 서 흡광도를 측정하였다.

글루타민산나트륨 함량은 액체 크로마토그래피에 의해 glutamic acid(GA)로서 정량하고 monosodium glutamic acid(MSG)의 양은 glutamic acid에 분자량비를 곱해서 환산 하였다.

\section{타르색소 함량 측정}

훈제오리의 타르색소 분석(30)을 위해 시료 $10 \mathrm{~g}$ 을 취한 후 분쇄한 석유에테르 $100 \mathrm{~mL}$ 로 2회 추출하여 지방을 포함 한 추출액은 버리고 $2 \sim 5$ 배의 물을 가한 후, 가끔 흔들어 혼합하면서 $80^{\circ} \mathrm{C}$ 수욕상에서 가온하여 색소를 추출한 후 그 액을 원심분리하여 상층액을 취하였다. 잔류물이 여전 히 착색되어 있는 경우 $1 \mathrm{~N}$ 염산을 가해 상기 조작 방법을 반복하여 모든 상층액을 합한 후 $1 \%$ 암모니아수 또는 $1 \%$ 초산으로 $\mathrm{pH}$ 5 6으로 조정하였다. 전처리 된 Sep-pak C18 cartridge에 시료 용액 전량을 흘려보내 색소를 흡착시킨 후 증류수 $10 \mathrm{~mL}$ 로 세정하였다. 이어 cartridge에 $0.1 \%$ 염산- 
메탄올용액 $10 \mathrm{~mL}$ 및 $1 \%$ 암모니아성 메탄올 $2 \mathrm{~mL}$ 를 순차 적으로 가하여 색소를 용출시킨 후 증발 농축하였다. 잔류 물에 $0.1 \%$ 암모니아수 $1 \mathrm{~mL}$ 를 가하여 녹인 후 물을 가하여 $10 \mathrm{~mL}$ 로 정용하고 $0.45 \mu \mathrm{m}$ filter로 여과하여 HPLC(Agillent 1100 series, Agilent, Santa Clara, CA, USA)로 분석하였다.

\section{$\mathrm{pH}$ 측정}

시료 $10 \mathrm{~g}$ 을 증류수 $90 \mathrm{~mL}$ 에 희석시키고 $\mathrm{pH}$ meter $(\mathrm{pH}-200 \mathrm{~L}$, Schawarzenbach, Switzlerland)로 5 회 반복 측정 하여 평균값을 구하였다.

\section{생균수 측정}

훈제오리의 총 균수와 대장균군 검사는 각 시료 $10 \mathrm{~g}$ 에 멸균증류수 $90 \mathrm{~mL}$ 를 첨가하여 Stomacher(LB W400, TMC, Seoul, Korea)를 이용하여 1 분 동안 균질화한 후 $1 \mathrm{~mL}$ 를 채취하여 $3 \mathrm{M}$ petrifilm plate(일반세균: aerobic count plates, 대장균군: E.colij/coliform count plate, USA)에 분주하여 배 양기에서 $37^{\circ} \mathrm{C}, 24 \sim 48$ 시간 배양하였으며 colony 수를 계수 하여 $\mathrm{CFU} / \mathrm{g}$ 으로 나타내었다.

\section{색도 측정}

훈제오리고기의 육색은 색차계(Spectrophotometer, CM3500D, Minolta Corporation, Ltd., Japan)를 이용하여 Hunter L(lightness, 명도), a(redness, 적색도) 및 b(yellowness, 황색 도) 등을 각각 5 회 이상 측정하여 평균값을 구하였다. 이때 표준색은 $\mathrm{Y}=93.5, \mathrm{X}=0.3132, \mathrm{y}=0.3198$ 인 표준색판을 사용 하여 표준화 한 후 측정하였다.

\section{기호도 평가}

관능적 특성변화는 정확한 소비자의 관점에서 평가하기 위해 20 50대 소비자 100명을 무작위로 선별하여 9점 척도 (9-point hedonic scale)를 사용하여 저장기간에 따른 관능적 기호도 평가를 실시하였다. 관능평가를 실시하기 전 평가 항목에 대한 기초적인 방법에 대해 설명 한 후 평가를 무작 위로 배열시킨 뒤 실시하였다. 평가 항목으로는 외관, 냄새, 색깔, 질감, 맛, 후미, 전체적인 기호도를 선정하여 실시하 였다. 3 회 반복하여 실시하였으며 결과는 평균과 표준편차 로 나타내었다

\section{총 폴리페놀 함량 측정}

훈제오리 $10 \mathrm{~g}$ 에 에탄올 $40 \mathrm{~mL}$ 를 넣어 실온에서 48 시간 추출한 후 $3,000 \mathrm{rpm}$ 으로 10 분간 원심분리하여 상층액을 시료로 사용하였다. 시료의 총 폴리페놀 함량은 $\mathrm{AOAC}$ 의 Folin-Denis법(31)을 일부 수정하여 Folin-reagent가 추출물 의 페놀성 화합물에 의해 환원되어 몰리브덴청색으로 발색 되는 원리를 이용하여 정량하였다. 즉 각 시료 $100 \mu \mathrm{L}$ 에 $2 \% \mathrm{Na}_{2} \mathrm{CO}_{3} 2 \mathrm{~mL}$ 를 넣어 30 분간 방치한 후 $50 \%$ folin- ciocalteu 시약 $100 \mu \mathrm{L}$ 넣은 후 혼합하여 30 분간 방치하고 spectrometer(Gene Spec III, JP/U-3010, Hitachi, Ibaraki, Japan)를 이용하여 $750 \mathrm{~nm}$ 에서 흡광도를 측정하였다. 표준 물질로는 gallic acid를 사용하였으며, gallic acid 검량선과 비교하여 총 폴리페놀 함량 $(\mathrm{mg} / 100 \mathrm{~g})$ 을 구했다. 실험은 반복 수행하여 평균값을 사용하였다.

\section{$\mathrm{DPPH}$ 라디칼 소거능 측정}

$\mathrm{DPPH}$ 라디칼 소거능은 안전한 라디칼인 2,2-Diphenyl-1picrylhydrazyl(DPPH)에 대한 환원력을 측정한 것으로 Blios법(32)을 변형하여 측정하였다. 즉, $99.9 \%$ 에탄올에 녹인 $0.2 \mathrm{mM} \mathrm{DPPH}$ 용액 $0.8 \mathrm{~mL}$ 과 농도별로 희석한 각 시료 $0.2 \mathrm{~mL}$ 를 가하여 잘 혼합하고 30 분간 실온에 방치하 였다. 이후 DPPH 용액의 흡광도를 spectrometer(Gene Spec III, JP/U-3010, Hitachi, Ibaraki, Japan)를 이용하여 $520 \mathrm{~nm}$ 에 서 측정하였다. DPPH 라디칼 소거능은 시료첨가구와 비첨 가구의 흡광도 차이를 백분율로 표시하였다. 양성 대조물 질로는 BHT(Butylated hydroxy toluene) 100 을 사용하였다.

$$
\begin{gathered}
\mathrm{DPPH} \text { 라디칼 소거능(\%)=[1-(실험구의 흡광도/대조구의 } \\
\text { 흡광도)]×100 }
\end{gathered}
$$

\section{통계분석}

실험결과의 통계분석은 SPSS/Windowa 18.0(Statistical Package for the Social Science Inc., Chicago, IL, UAS)를을 이용하여 통계처리 하였고, 결과를 평균표준편차로 나타 내었다. 두 실험군간의 유의성은 t-test로 검증하였고, 셋 이상의 각 군 간의 유의성은 ANOVA를 이용하여 검증한 후 Duncan's multiple range test로 변인간의 차이를 검증하 였다. 모든 통계적인 유의성은 $a=0.05$ 수준에서 검증하였 다.

\section{결과 및 고찰}

\section{식품 첨가물 잔류량}

천연 염지제를 이용한 훈제오리의 식품 첨가물 잔류량은 Table 2 와 같다. 일반훈제오리는 아질산염 $0.03 \mathrm{mg} / \mathrm{kg}$, 에리 솔빈산 $7.2 \mathrm{mg} / \mathrm{kg}$, 글루타민산나트륨 $0.02 \mathrm{mg} / \mathrm{kg}$, 타르색소 $0.4 \mathrm{mg} / \mathrm{kg}$ 검출되었다. 이 중 아질산염은 Lee 등(33)의 자색 고구마 분말과 자색 색소를 이용한 소시지 연구 결과에서 저장 10 일 후 아질산염 잔류양이 $0.03 \mathrm{mg} / \mathrm{kg}$ 인 결과와 유사 하였다. 그리고 아질산염은 마늘과 양파를 첨가한 소시지 연구(34)에서 식품 제조 초기보다 저장하는 동안 감소한다 는 보고에 따르면 훈제오리를 저장동안 그 함량이 감소할 것으로 판단된다. 그러나, 일반 훈연육의 발색제로 쓰이는 아질산염을 다량으로 섭취하게 되면 혈액의 hemoglobin을 methemoglobin으로 산화시켜 methemoglobin증을 일으키 
는 중독 증상을 유발하고 제 2 급 및 제 3 급 아민류와 반응하 여 발암성 nitrosamine을 생성하기도 한다. 그래서 식육가공 품의 경우 잔존 아질산 이온의 양을 $0.07 \mathrm{~g} / \mathrm{kg}$ 으로 제한하고 있다(15). 산화방지제인 에리솔빈산은 산화방지제 이외의 목적으로는 사용 금지되어 있어 대상 식품별 사용량이 정해 져 있지 않다. 또한 식품첨가물로서 효과를 얻기 위해 필요 한 양 또는 식품 중에 존재하는 양으로부터 해당 첨가물을 매일 섭취하여도 위해하지 않으므로 1 일 섭취 허용량(ADI, Acceptable Daily Intake)를 설정할 필요가 없는 식품첨가물 이다. 본 연구의 일반훈제오리에서 검출된 에리솔빈산의 양은 $7.2 \mathrm{mg} / \mathrm{kg}$ 으로 식품의 약품안전처와 한국보건산업진 흥원이 조사 발표한 어육소세지 $70.5 \mathrm{mg} / \mathrm{kg}$ 보다는 유의적 으로 적은 양이었다(35). 타르색소는 Kim 등(36)의 어린이 기호식품 즉, 초콜릿, 껌, 건과류, 캔디류, 청량음료 등에 함유된 각각 47.66, $42.82,26.59,28.41,16.68 \mathrm{mg} / \mathrm{kg}$ 함량보 다는 유의하게 적었다. 훈제육은 타르색소 보다는 발색제 나 $\mathrm{pH}$, 식육의 보수력 등 다른 요인에 의해서도 육색이 좌우되기 때문으로 판단된다. 천연훈제오리는 아질산염, 산화방지제 및 글루타민산나트륨, 타르색소는 검출되지 않 았다. 이는 천연 염지액 성분에 식품첨가물이 들어가지 않 았고 배당침액, 천연발색제인 셀러리파우더, 비타민 C 등 천연 염지제를 사용했기 때문으로 사료된다. 특히, 비타민 $\mathrm{C}$ 는 훈연육 염지 시 아질산염에서 산화질소로 진행되는 것을 감소시키고 염지반응을 촉진하기 위하여 부가적으로 사용되어 왔음을 생각해 볼 때(37) 이는 훈제오리 제조 시 붉은 육색 발현에 직접적인 영향을 미치는 화학첨가제인 아질산염 또는 오리시즈닝을 사용하는 것 보다는 비타민 $\mathrm{C}$ 나 셀러리파우더 같이 붉은색 발현에 간접적으로 도움을 주는 재료를 사용하는 것이 소비자에게 긍정적인 영향을 미칠 것으로 판단된다. 육류 업계에서는 육제품에 잔존하 아질산염 양으로는 methemoglobin증이나 발암성 nitrosamin 생성을 우려할 정도가 아니라고 보고되고 있으 나 일반 소비자들은 식품안전에 불안을 느끼는 요인으로 '보존료, 착색료 등의 식품첨가물'이라고 하였다(38). 그래 서 잠재적으로 그 사용을 줄이기 위해 많은 연구자들이 자색 고구마 색소(33), 비트 색소(39), 선인장 색소(40) 및

Table 2. The food additivies and tar color contents of smoked ducks added with pear extracts

\begin{tabular}{ccc} 
& & (unit: $\mathrm{mg} / \mathrm{kg}$ ) \\
\hline Inspection Item & $\mathrm{GSD}^{1)}$ & $\mathrm{NSD}^{2)}$ \\
\hline Nitrite ion & $0.03 \pm 0.0$ & $\mathrm{ND}^{3)}$ \\
Antioxidant & $7.2 \pm 2.0$ & $\mathrm{ND}$ \\
Monosodium glutamate & $0.02 \pm 0.0$ & $\mathrm{ND}$ \\
Tar color & $0.4 \pm 0.0$ & $\mathrm{ND}$ \\
\hline
\end{tabular}

${ }^{1)} \mathrm{GSD}$, general smoked duck.
${ }^{2} \mathrm{NSD}$, natural smoked duck.

${ }^{3)} \mathrm{ND}$, Non-detection.
홍국 색소(41) 등을 이용하여 아질산염을 부분 대체하는 연구를 진행되고 있다. 따라서 천연 색소를 이용한 훈연육 들이 계속적으로 개발되어 소비자에게 보급률이 늘어나면 아질산염의 이용은 자연적으로 점점 감소할 것으로 사료된 다.

\section{$\mathrm{pH}$ 변화}

가공한 훈제오리를 45 일 동안 냉장보관하면서 실시한 $\mathrm{pH}$ 변화를 측정한 결과는 $\mathrm{Fig}$. 3 과 같다. 훈제오리의 저장 첫날 $\mathrm{pH}$ 는 일반훈제오리가 $\mathrm{pH} 6.5$, 천연훈제오리 $\mathrm{pH} 6.4$ 이었으나 저장 45 일째에는 일반훈제오리가 $\mathrm{pH} 6.4$, 천연훈 제오리 $\mathrm{pH}$ 6.29로 감소하는 경향을 보였는데 유의적인 차 이는 거의 없었다. 훈제오리는 가공 후 밀봉 포장으로 인해 산소공급이 중단되면서 혐기적인 화학작용으로 젖산이 생 성되어 저장기간이 오래됨에 따라 $\mathrm{pH}$ 가 감소하게 되는데, 이는 미생물의 성장에 따른 젖산 생성 때문으로 사료된다 (42). 또한 Browm 등(43)의 연구 결과에 의하면 오리고기의 $\mathrm{pH}$ 가 낮을 때 육색소인 마이오글로빈의 산화가 잘 일어나 기 때문에 매트마이오글로빈의 축적은 높은 $\mathrm{pH}$ 를 가진 식 육보다 낮은 식육에서 더 많은 변색과 빠른 축적을 가져온 다고 하였다. 따라서 저장기간 동안 천연훈제오리의 $\mathrm{pH}$ 가 일반훈제오리의 $\mathrm{pH}$ 보다 낮아지면서 자연스럽게 훈제오리 의 분홍빛을 나타내는 것으로 사료된다.

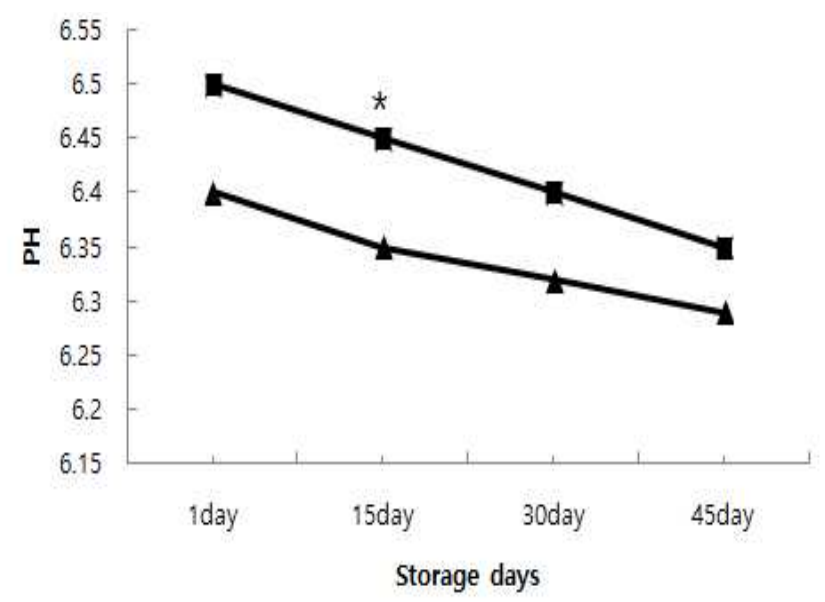

Fig. 3. Changes in $\mathrm{pH}$ of GSD and NSD during the storage at $4{ }^{\circ} \mathrm{C}$

-, GSD (general smoked duck); - $\mathbf{A}$-, NSD (natural smoked duck). Values with between the two sample are significantly different at $\mathrm{p}<0.05$.

\section{생균수 변화}

천연 염지제를 이용하여 가공한 훈제오리의 일반 세균과 대장균군수 측정은 가공한 훈제오리를 45 일 동안 냉장보관 하면서 실시하였다. 일반세균은 두 군 모두 저장기간 동안 약간의 미생물이 검출되었지만 유의하지 않았고 대장균군 은 두 군 모두 검출되지 않아 결과자료는 따로 제시하지 않았다. 이러한 결과는 두 군 모두 진공포장하여 냉장보관 함으로써 공기 중의 미생물로 부터 차단되고 저온에서 미생 
물의 활동이 억제되기 때문으로 사료된다. 일반훈제오리는 아질산나트륨이나 산화방지제와 같은 식품첨가물이 항균 작용까지 병용하고 특히, 아질산나트륨이 Clostridium botulinum의 성장과 독소 생성 억제 및 미생물의 생장을 억제 $(15,44)$ 해 주는 것으로 판단된다. 천연훈제오리는 염 지제 성분 중 배당침액 내 폴리페놀 성분의 항균효과(17) 뿐 아니라 비타민 $\mathrm{C}$ 와 천연염지제 속의 마늘이나 양파 등의 미생물 성장 억제 효과(40)가 있어 나타난 결과라 사료된다. 식품첨가물을 첨가하지 않아도 천연염지제만으로도 일반 세균이나 대장균 등 식중독균의 발생을 억제할 수 있음을 보여주는 결과이다. 또 식육의 낮은 $\mathrm{pH}$ 는 식육의 보수력을 감소시키는 결정적인 원인으로 작용하기 때문에 천연훈제 오리의 보수력이 일반훈제오리의 보수력보다 낮아 저장기 간 동안 생균수의 억제에도 효과가 있다고 판단된다(2).

Table 3. Change in color of GSD and NSD during the storage

\begin{tabular}{cccccc}
\hline \multirow{2}{*}{ Color } & \multirow{2}{*}{ Sample } & \multicolumn{4}{c}{ Storage period (day) } \\
\cline { 3 - 6 } & & 1 & 15 & 30 & 45 \\
\hline \multirow{2}{*}{ L } & GSD $^{3)}$ & $62.8 \pm 0.7^{\mathrm{a} 22}$ & $57.9 \pm 4.2^{\mathrm{b}}$ & $56.1 \pm 2.1^{\mathrm{b}}$ & $56.1 \pm 2.6^{\mathrm{b}}$ \\
& $\mathrm{NSD}^{4)}$ & $60.9 \pm 2.8^{\mathrm{a}}$ & $59.5 \pm 3.8^{\mathrm{a}}$ & $58.4 \pm 1.9^{\mathrm{ab}}$ & $56.3 \pm 2.3^{\mathrm{b}}$ \\
\hline \multirow{2}{*}{$\mathrm{a}$} & $\mathrm{GSD}$ & $9.4 \pm 0.5^{\mathrm{a}^{*}}$ & $8.7 \pm 0.6^{\mathrm{b}^{\mathrm{b}}}$ & $8.5 \pm 1.0^{\mathrm{c}^{*}}$ & $8.3 \pm 0.8^{\mathrm{c}^{\mathrm{b}}}$ \\
& $\mathrm{NSD}$ & $8.5 \pm 1.3^{\mathrm{a}}$ & $7.7 \pm 0.9^{\mathrm{b}}$ & $7.8 \pm 0.4^{\mathrm{b}}$ & $7.6 \pm 0.9^{\mathrm{b}}$ \\
\hline \multirow{2}{*}{$\mathrm{b}$} & $\mathrm{GSD}$ & $12.4 \pm 0.9^{\mathrm{a}}$ & $10.9 \pm 1.3^{\mathrm{b}}$ & $9.8 \pm 1.1^{\mathrm{c}}$ & $9.6 \pm 1.6^{\mathrm{c}}$ \\
& $\mathrm{NSD}$ & $11.2 \pm 0.6^{\mathrm{a}}$ & $10.7 \pm 1.1^{\mathrm{ab}}$ & $10.3 \pm 0.7^{\mathrm{b}}$ & $10.0 \pm 1.1^{\mathrm{b}}$ \\
\hline
\end{tabular}

Hunter L, lightness; Hunter a, redness; Hunter b, yellowness.

${ }^{1)}$ Values with between the two sample are significantly different at $p<0.05$

${ }^{2 / a-c}$ Means \pm SD with different superscripts in the same column are significantly different $(p<0.05)$ by Ducan's multiple range test.

${ }^{3)} \mathrm{GSD}$, general smoked duck.

${ }^{4}$ NSD, natural smoked duck.

\section{색도변화}

가공한 훈제오리를 45일 동안 냉장보관하면서 실시한 색도 변화를 측정한 결과는 Table 3 과 같다. 훈제오리의 명도는 두 군간의 유의적인 차이를 보이지 않았으나 두 군 모두 저장기간이 길어질수록 명도가 감소하였다 $(\mathrm{p}<0.05)$. 적색도는 저장 전 기간 동안에 유의적으로 일반 훈제오리가 더 높았고 두 군 모두 저장 기간이 길어질수록 적색도는 감소하였다 $(\mathrm{p}<0.05)$. 황색도는 두 군간에는 유의 적인 차이를 보이지 않았으나 저장기간에 따라서는 두 군 모두 저장 첫날의 황색도가 가장 높았으며 저장 기간이 길어질수록 유의적으로 감소하였다 $(\mathrm{p}<0.05)$. 색도변화는 천연훈제오리에 아질산염이 첨가되지 않아 명도나 적색도, 황색도가 일반훈제오리 보다 낮게 나왔지만 저장 기간이 길어질수록 그 차이는 심하지 않았다. 그 이유는 Kang 등의 연구결과에서 보고한 천연염지제 속에 들어있는 L-ascorbic $\mathrm{acid}$ 가 오리육의 붉은색 발현에 간접적으로 도움을 줘 진공 텀블러에서 오리고기 조직 내 염지제가 충분히 침투하게 함으로써 염지육색소의 함량이 높게 나타난다(3)는 결과와 유사하였다. 그리고 천연발색제인 셀러리는 질산 함유량이 높고 셀러리 자체의 풍미가 육제품과 잘 어울리기 때문에 천연발색제 역할을 하기 때문으로 사료된다(23). 따라서 훈제오리 제조 시 보다 육색 발현에 직접적인 영향을 미치 는 아질산염 또는 오리시즈닝을 사용하는 것 보다는 간접적 으로 도움이 되는 L-ascorbic acid나 셀러리 같은 천연 발색 제를 사용하는 것이 소비자의 안전한 먹거리 신뢰구축에는 긍정적인 영향을 미칠 것으로 사료된다.

\section{관능평가}

가공한 훈제오리의 저장기간 동안의 기호도 평가 결과는 Fig. 4와 같다. 맛이나, 질감, 전체적인 품질에 대한 기호도 (a)

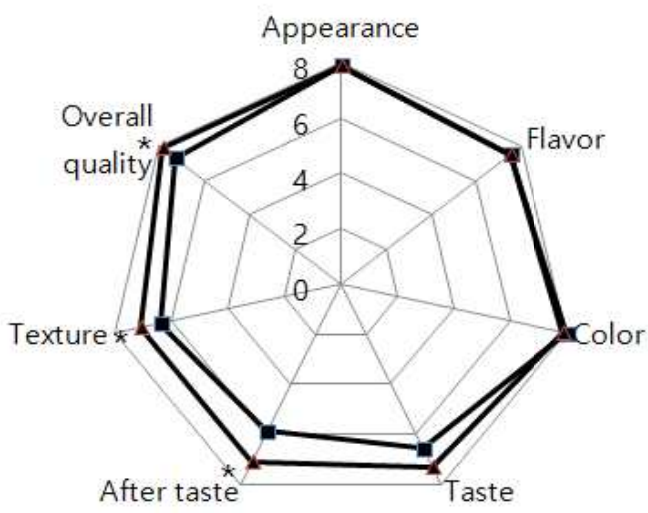

(b)

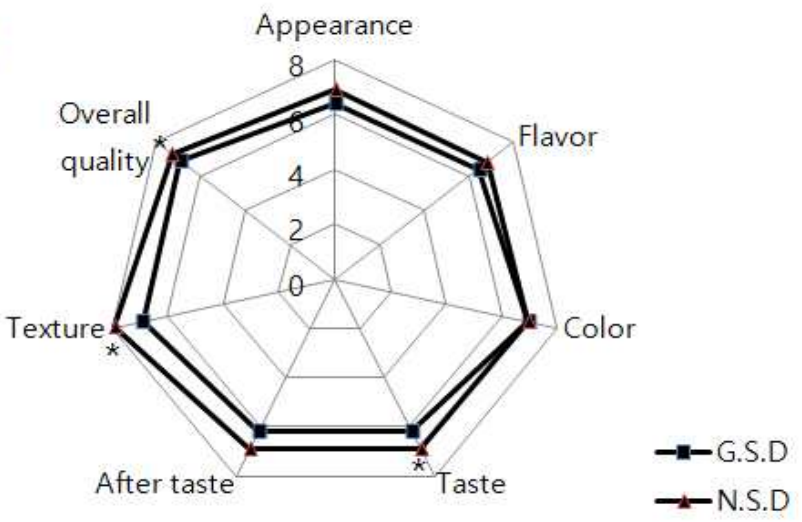

Fig. 4. Change in preference of the GSD and NSD smoked ducks during storage for 1 day (a) and 45 days (b).

Values with between the two samples are significantly different at $\mathrm{p}<0.05$ GSD, general smoked duck; NSD, natural smoked duck 
는 유의적으로 천연훈제오리의 평가가 높았다. 또한 기호 도 평가에 영향을 미치는 요인을 정량적묘사분석 (quantitative descriptive analysis, QDA)도표를 보면 저장 1 일째는 전체적인 품질에 영향을 미치는 요인으로 외관, 냄새, 색깔, 질감, 맛, 후미 등의 순이었다. 저장 전 기간을 통하여 질감, 후미, 맛, 전체적인 기호도에서 천연훈제오리 가 유의적으로 높았다( $\mathrm{p}<0.05)$. 훈제오리에 대한 기호도 관 능평가는 저장 기간이 길어질수록 외관, 색, 맛, 후미, 질감, 전체적인 품질이 유의적으로 감소하였다 $(\mathrm{p}<0.05)$. 그러나 맛이나, 질감, 전체적인 품질에 대한 기호도는 저장 기간 내내 유의적으로 천연훈제오리의 평가가 높았다( $\mathrm{p}<0.05)$. 이는 천연물 소재를 이용한 훈제오리는 L-ascorbic acid만 사용하더라도 훈연 오리의 분홍색 발현에 효과적이라는 보고(3)와 같이 천연훈제오리의 전반적인 외관이나 맛, 풍 미 등이 일반훈제오리보다 더 우수하였기 때문으로 사료된다.

본 연구를 통해 천연염지제를 첨가한 천연훈제오리는 그 품질 및 저장성이 일반훈제오리보다 높은 것으로 검토되 었기에 향 후 식품첨가물을 대신하는 더 많은 천연물 소재 가 개발되고 이를 이용한 생리활성 연구, 위생 - 안전 및 영양적으로도 우수한 가공 산업이 발전할 수 있기를 기대해 본다.

훈제오리의 총 폴리페놀 함량 및 DPPH 라디칼 소거능

천연 염지제를 이용한 훈제오리의 총 폴리페놀 함량을 측정한 결과는 Fig. 5 와 같다. 천연 소재를 이용한 훈제오리 의 총 폴리페놀 함량이 $107 \pm 2.4 \mathrm{mg} / 100 \mathrm{~g}$ 으로 $55 \pm 3.5$ $\mathrm{mg} / 100 \mathrm{~g}$ 인 일반오리훈제보다 유의적으로 높았다 $(\mathrm{p}<0.05)$. 이는 본 연구의 배당침액의 재료인 신고의 과피에는 arbutin, catechin, epicatechin, chlorogenic acid가 함유되어 있고(45), 특히, 동양배에 페놀성 화합물로 chlorogenic acid, epicatechin, 4-HMBA 등이(46) 많이 함유되어 나타난 결과로 사료된다. 또한 배에 많이 함유되어 있는 페놀성 화합물들은 식품계에 널리 분포되어 있는 2 차 대사산물로 천연 또는 가공식품의 기호성과 영양가에 밀접한 관계를 가지고 있으며, 천연 항산화제 혹은 항돌연변이, 항발암효 과 등 인체에 다양한 생리활성을 나타낸다고 $(23,47)$ 보고되 어 배당침액을 첨가한 훈제오리는 안전하게 섭취할 수 있을 것으로 사료된다. 셀러리는 피를 맑게 하고 혈압을 내리게 하는 효과, 류머티즘 치료 효과 등에 관여하는 특성이 있으 며(25), 비타민 C는 천연 항산화제로 유리라디칼에 전자를 줌으로써 비타민 $\mathrm{E}$ 와 함께 유리라디칼 제거제로 작용하고 면역 수행 중 유리라디칼로부터 생기는 산화적 손상을 막아 면역작용을 향상시키는 작용(26) 등이 있다. 따라서 천연훈 제오리의 총 폴리페놀 함량이 일반훈제오리보다 유의적으 로 높게 $(\mathrm{p}<0.05)$ 나온 것은 배, 셀러리, 비타민 $\mathrm{C}$ 와 같은 천연소재의 기능성 성분 함량에 기인한다고 생각된다.

천연 염지제를 이용한 훈제오리의 DPPH 유리라디칼 소
거능을 측정한 결과는 Fig. 5 와 같다. DPPH 라디칼 소거능 은 천연훈제오리가 $85.2 \%$ 로 일반훈제오리 $50.8 \%$ 보다 유의 적으로 높았다 $(\mathrm{p}<0.05)$. 대조군으로 사용한 BHT 100 의 라 디칼 소거능인 $20.6 \%$ 보다 약 4 배 정도 라디칼 소거능이 우수함을 알 수 있었다. 결과적으로 폴리페놀 함량이 높고 항산화 활성이 높은 배와 셀러리, 비타민 C 등이 천연염지 제 성분으로 사용되어 천연 훈제오리의 총 폴리페놀 함량이 높고 이에 따라 유리 라디칼을 소거하는 항산화활성도 높은 것으로 사료된다.

결론적으로 배당침액, 셀러리파우더, 비타민 $\mathrm{C}$ 를 포함한 천연염지제는 일반훈제오리 염지제를 대신할 수 있으며, 천연물을 이용하여 개발한 천연훈제오리는 합성첨가물이 나 미생물 등이 검출되지 않고 항산화 활성이 우수하여 일반 소비자가 더 믿고 찾을 수 있는 위생적이고 안전한 건강식품으로써 적합하다고 판단된다.

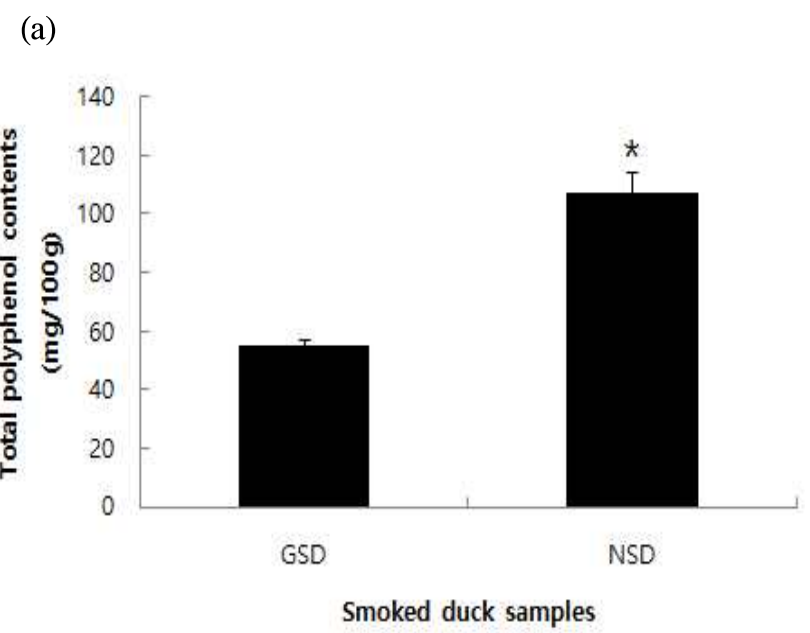

(b)

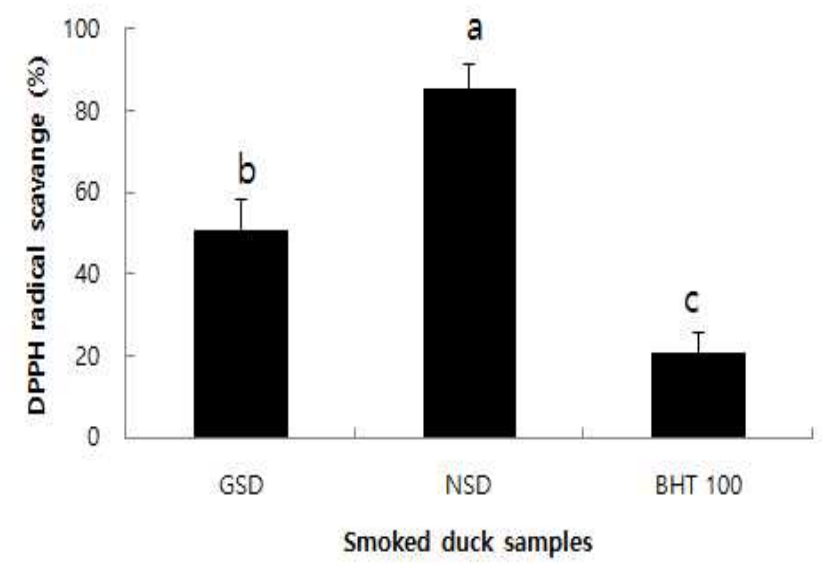

Fig. 5. The total polyphenol contents (a) and DPPH radical scavenging activities (b) of GSD and NSD smoked ducks.

Values with between the two sample are significantly different at $p<0.05$. ${ }^{\mathrm{ac}} \mathrm{Means} \leq \mathrm{SD}$ with different superscripts in the same column are significantly different $(p<0.05)$ by Ducan's multiple range test.

GSD, general smoked duck; NSD, natural smoked duck. 


\section{요 약}

본 연구는 천연 소재를 이용하여 개발한 천연훈제오리의 품질 특성을 일반훈제오리와 비교하여 합성 염지제를 천연 물로 대체 가능한지를 알아보았다. 또한 소비자가 믿고 찾 을 수 있는 안전하고 위생적인 식품으로 더 적합한 훈제오 리를 개발하고자 하였다. 식품첨가물 잔류량, 저장기간 동 안 훈제오리의 $\mathrm{pH}$, 미생물량 및 색도변화, 관능평가, 항산 화활성 등을 조사하였다. 천연물을 이용하여 개발한 천연 훈제오리에서는 아질산나트륨, 산화방지제, 글루타민산나 트륨 등의 합성첨가물은 검출되지 않았다. 저장 기간 동안 두 군 모두 $\mathrm{pH}$ 가 감소하는 경향을 보였으며 대장균군은 발생하지 않았다. 훈제오리의 명도와 황색도는 두 군 간에 차이가 없었으나 저장기간 동안 두군 모두 감소하였으며, 적색도는 저장 전 기간 동안 일반 훈제오리가 유의적으로 높았다. 훈제오리에 대한 기호도 평가는 저장 기간이 길어 질수록 외관, 색, 맛, 후미, 질감, 전체적인 품질이 유의적으 로 감소하였으나 맛이나, 질감, 전체적인 품질에 대한 평가 는 저장 기간 내내 유의적으로 천연훈제오리의 평가가 더 높았다. 총 폴리페놀 함량과 항산화 활성은 천연훈제오리 가 일반훈제오리보다 높았다. 이상과 같은 결과로 볼 때 배당침액, 셀러리파우더, 비타민 $\mathrm{C}$ 를 포함한 천연염지제는 일반훈제오리 염지제를 대신할 수 있으며, 천연물을 첨가 하여 개발한 천연훈제오리는 식품첨가물이나 미생물 등이 검출되지 않고 항산화 활성이 우수하여 일반 소비자가 더 믿고 찾을 수 있는 위생적이고 안전한 건강식품으로써 적합 하다고 사료된다.

\section{References}

1. KDA (Korea Duck Association). Available from: http: //www.koreaduck.org/

2. Kang GH, Jeong TC, Yang HS, Kim SH, Jang BG, Kang HS, Lee DS, Lee SJ, Joo ST, Park GB (2006) Effects of packaging methods on color and lipid oxidation of duck meat during cold storage. Korean J Poult Sci, 1, 7-14

3. Kang GH, Cho SH, Seong PN, Park KM, Kang SM, Park BY (2013) Effect of curing additives on color property of smoked duck meat. Korean J Poult Sci, 3, 179-185

4. http://www.urinews.co.kr/sub_read.html?uid=31349

5. http://www.korea.kr/policy/societyView.do?newsId= 148802665

6. Kim YO (2012) Manufacturing method for smoking of duck meat containing tangle extract liquid. Final Report of KOSEF, KOSEF 10-1139514

7. Shinchoun FD (2010) Method for manufacturing smoked duck containing curcuma longa L. ingredient. Final Report of KOSEF, KOSEF 10-0948262

8. Sim JH, Sim JL, Sim JH, Kim HJ, Kim CH (2010) Method for producing smoked sulfur duck using wild plants fermented broth and smoked sulfur duck produced by the same. Final Report of KOSEF, KOSEF 10-0988138

9. Hanseong Food (2010) Smoking of duck meat containing mulberry and that of manufacturing method. Final Report of KOSEF, KOSEF 10-1291242

10. Kim YJ, Kim MB, Moon YI, Kim YB (1991) Processing of brine soaked and smoked duck meat: I . Pan-broilling yield and sensory evaluation of brined or smoked duck meat. Korean J Sci Ani Resour, 12, 852-856

11. Kim YJ, Kim MB, Moon YY, Kim YB (1991) Processing of brine soaked and smoked duck meat: П. Properties of brined or smoked duck meat during storage. Korean J Sci Ani Resour, 12, 857-861

12. Joint FAO/WHO (2001) Safety evaluation of certain food additives and contaminants. WHO Food Additives Series, 49, 1021-1044

13. Food processing\&preservation. Soohaksa, Seoul, Korea, p 324

14. Oh JW (2010) Allergic diseases in childhood and food additives. Pediatr Allergy Respir Dis, 10, 212-218

15. Korean Food and Drug Administration (2013) The livestock processing act. Cheongju, Korea, p 51

16. Natural drug research and development promotion 1 of Article 2

17. Her J (2007) Donguibogam, Korea, p 1801

18. Kim JB (2003) Story of our pear, National Institute of Horticultural \& Herbal Science. Horticulture research, Suwon, Korea, 18-22

19. Zhang YB, Choi HJ, Han HS, Park JH, Son JH, Bae JH, Seong TS, An BJ, Kim HG, Choi C (2003) Chemical structure of polyphenol isolated from Korean pear (Pyrus pyrifolia Nakai). Korean J Food Sci Technol, 35, 959-967

20. Escarpa A, Gonzalez MC (1999) Fast separation of (poly) phenolic compounds from apple and pears by highperformance liquid chromatography with diode-array detection. J Chromatog A, 830, 301-309

21. Oleszek W, Amot MJ, Aubert SY (1994) Identification of some phenolics in pear fruit. J Agric Food Chem, 42, 1261-1265

22. Sharma A, Sehgal S (1992) Effect of domestic processing, cooking and germination on the trypsin inhibitor activity 
and tannin content of faba bean (vicia faba). Plant Foods Hum Nutr, 42, 127-133

23. Yang $\mathrm{MH}$, Park $\mathrm{CH}$, Kim DJ, Jeong HS (2005) Antimutagenic and anticarcinogegnic effects of Korean pears. J Cancer Prevention, 10, 124-127

24. http://academy.foodbank.co.kr/news/view.php? $\mathrm{No}=$ $2425 \&$ cat_name $=$ cat_name $\&$ secIndex $=22892 \&$ page $=$ 28\&section $=001003 \&$ back $=\mathrm{H}$

25. Nation Korean medicine laboratory. Private oriental medicine. (2006) p 91-92

26. Gu JO, Lim HS, Yun JS, Lee YL, Ser JS, Lee JH, Son JM (2013) Advanced nutrition. Powerbook Co., Seoul, Korea, p 371-373

27. Pear Research Station (2010) National Institute of Horticultural \& Herbal Science. industrial condition and activation plan of pear. p 3

28. AOAC (1995) Official Methods of Analysis 15th ed, Association of Official Analytical Chemist, Washington DC, USA, p 777-784

29. Tanimura A, Fujii M, Yoshihira K, Ito Y, Shiro T (1992) Analytical methods for additives in foodstuff. Tokyo: Kodan Scientific Co., p 94-101

30. Korea Food Industry Association. (2001) Food Code. Cheaongju, Korea, p 539-564

31. Swain T, Hillis WE (1959) The phenolic constituents of Prunus domestica I -The quantitative analysis of phenolic constituents. J Sci Food Agric, 10, 63-68

32. Blois MS (1958) Antioxidant determination by the use of a stable free radical. Nature, 181, 1199-1120

33. Lee NR, Jo YJ, Yook HS (2015) Quality characteristics and antioxidant activities of sausages made from a mixture of purple sweet popato powder and purple sweet potato pigment. J Korean Soc Food Sci Nutr, 44, 1317-1324

34. Park WY, Kim YJ (2009) Effect of galic and onion juice addition on the lipid oxidation, total plate counts and residual nitrite contents of emulsified sausage during cold storage. Korean J Food Sci An, 29, 612-618

35. Ministry of Food and Drug Safety and Korea Health Industry Development Institute (2008) Right understand of food additives. Cheaongju, Korea, p 12
36. Kim HY, Nam HS, Jung YH, Lee JH, Ha SC (2008) Tar colors in foods distributed throughout the Gyeong-in region: monitoring favorite food item of children near elementary schools. Korean J Food Sci Technol, 40, 243-250

37. Shahidi F, Pegg RB (1992) Nitrite-free meat curing systems: update and review. Food Chem, 43, 185-191

38. Lee SM (2013) A study on the quality characteristics of gruel supplemented with purple sweet potato. J East Asian Soc Dietary Life, 23, 234-240

39. Kang JO, Lee GH (2003) Effects of pigment of red beet and chitosan on reduced nitrite sausages. Korean J Food Sci An, 23, 215-220

40. Kang JO, Lee SG (2008) Effects of Opuntia ficus-indica pigment and sodium lactate on nitrite-reduced sausages. J Anim Sci \& Technol, 50, 551-560

41. Rhyu MR, Kim EY, Chung KS (2003) Effects of Monascus koji on the quality characteristics of bolognatype sausage. Korean J Food Sci Technol, 35, 229-234

42. Park GB, Hur SJ, Lee JR, Lee JI, Kim YH, Ha YL, Joo ST (2000) Effects of onion peel components on lipid oxidation and the changes of color in press ham. Korean J Food Sci An, 2, 93-100

43. Brown WD, Mebine LB (1969) Antioxidation of oxymyoglobins. J Biol Chem, 244, 6696-6701

44. Cassens RG (1990) Nitrite cured meat. A food safety issue in perspective. Food and Nutrition Press Inc. Trumbull conn, USA, p 172-177

45. Kang HK, Yoo YK, Lee SK (2003) Effects of prestorage heat treatment on changes of phenolic compound contents and incidence of skin blackening in 'Niitaka' pear fruits during cold storage. J Korean Soc Hort Sci, 44, 197-200

46. Seo JH, Hwang YS, Chun JP, Lee JC (2001) Changes of phenolic compounds and occurance of skin browning and characterization of partically purified polyphenol oxidase in oriental pear fruits. J Korean Soc Hort Sci, 42, 184-188

47. Ho CT, Lee CY, Huang MT (1992) In phenolic compounds in food and their effects on health 1. Maple press, NY, USA, p 2 